\title{
Hilmi Uçan, Edebiyat Bilimi, İz Yayıncılık, İstanbul 2018, 231 Sayfa.
}

\author{
Zeynep Büşra BEKİROĞLU*
}

\begin{abstract}
"Okuyucu/eleştirmen soğukkanlılıkla, yazarın, yazarın yaşam öyküsünün, yazar hakkındaki reklamın gölgesinde kalmadan, çıkar gözetmeden, kendisi de 'içten' davranan, ideolojik yargısını dayatmadan R.Barthes'ın deyişiyle 'çok yüzlü bir küp' olan yazınsal metindeki biçim ve 'içerik'i gözlemlemeli, çözümlemeli: ‘öteki'nin, 'başka'nın söylemini kavramalı, anlamalıdır. İnsan ancak anladıktan sonra bir değer yarg1sı belirtebilir, bir yorum yapabilir. Anlamadan nasıl değerlendirilir? Okuyucu/ eleştirmen, daha ilk başta, Todorov'un deyişiyle 'metinde ne anlatılıyor?' 'Nasıl anlatılıyor?' sorularının yanıtını aramalıdır." (s.14)

Hilmi Uçan’ın Edebiyat Bilimi ${ }^{l}$ kitabının giriş bölümünden alınan bu ifade, eserin içeriği hakkında bilgi vermesi bakımından önemlidir. Yukarıdaki cümleleriyle çalışmasının genel çerçevesini çizen yazar dil, metin, okuyucu, eleştiri kavramlarından hareketle kuramsal bilgilere yer vererek kuramların edebiyat bilimi için önemini örnekler üzerinden ele alır.
\end{abstract}

Göstergebilim, yapısalcılık, edebiyat kuramı, eleştiri, öykü, edebiyat eğitimi gibi konuları barındıran eser, genelde tüm edebiyat alanlarını, özelde Yeni Türk Edebiyatı için önemli konuları ele alır. Eser ana hatlarıyla iki bölümden oluşmaktadır. Birinci bölüm "Edebiyat Bilimi ve Eleştiri” ana başlı̆̆ı altında dokuz kısımdan meydana gelir. Kitabın “Üslup Arayışları / Kısa Öykü / Küçürek Öykü” başlıklı ikinci bölümü ise dört alt başlığa ayrılır. Uçan son olarak "Kaynakça” ve "Dizin” kısımlarıyla eserini tamamlar.

\footnotetext{
* İstanbul Medeniyet Üniversitesi. SBE Türk Dili ve Edebiyatı Yüksek Lisans Öğrencisi.

Elmek: zeynepb.bekiroglu@gmail.com

https://orcid.org/0000-0003-3979-5464

1 Hilmi Uçan, Edebiyat Bilimi, İz Yayıncılık, İstanbul 2018.
} 
“Edebiyat Bilimi ve Eleştiri” ana başlıklı kısmın birinci bölümü “Okuyucu, Eleştiri ve Göstergebilim” başlığını taşır. Bu bölümde, bir esere yazarmetin-okuyucu bağlamında eleştirel yaklaşırken yazarın yaşam öyküsünden değil metinden hareket edilmesi gerektiği üzerinde durulur. Bu yaklaşım tarzının doğruluğunun ne derece geçerli olduğunu da R. Barthes, A. J. Greimas gibi göstergebilim kuramcılarının görüşleriyle destekler.

İkinci bölümde "Eleştiri Yöntemleri ve Göstergebilimsel Eleştiri” başlığ1 altında eleştiri kavramının tarihsel gelişiminden hareketle yazınsal ürünlere yaklaşım biçimleri ile ilgili yanlış düşüncelere ve bu düşüncelerin aksini savunan kuramsal bilgilere yer verilir. Sainte-Beuve ve Gustave Lanson gibi eleştirmenlerin metin yerine yazarı incelemeye aldıklarından bahseden Uçan, yazardan değil, metinden hareket edilmesi gerektiğini savunur. Metin eleştirisinin öznel duygulara göre değerlendirilen yapılar olmadığının vurgusu göstergebilimin yaklaşımlarına yer verilerek yapılır. Yazarın yaşam öyküsünden hareketle bir metnin yorumlanamayacağını, bunun yerine metinden hareket edilmesi düşüncesinden bahseden Yeni Eleştiri kuramı R.Barthes tarafından geliştirilir. Barthes bu iddiasını da "belli bir sistemi içeriden gözlemlemek" (s.29) sözüyle destekler. O, metnin derinine yani biçiminden çok içeriğine odaklanılması gerektiğini savunur. Buradan hareketle de Hilmi Uçan, sentaks üzerinden çözümleme yapan dilbilimcilerin aksine kelimeleri anlamlandırma yöntemiyle sağlıklı bir eleştiri anlayışı güden göstergebilimcilerin söylediklerini kabul eder.

Üçüncü bölüm “Dil, Yazar, Metin, Eleştiri Bağlamında Yapısalcılık”ın başlığını taşır. Bir önceki bölümde göstergebilime göre açıklanan kavramlar bu k1sımda yapısalcılık kuramı üzerinden değerlendirilir. Bölümün hareket noktası yapısalcılığın temelini oluşturan F.de Saussure'dir. Saussure: “Dil sadece kendi düzenini tanıyan sistemdir.” (s.39) diyerek, gelecekte bu sisteme 'yapı' diyecek olan Greimas'a kap1 aralar. “Dil”i, “yapı”yı meydana getiren yazar, yapısalc1lara göre kutsallaştırılmaması gereken, metni oluşturduktan sonra geri çekilmeyi bilmek zorunda olan kişidir ve Hilmi Uçan bu hususla ilgili yazarın değil 'dilin kullanımı'nın önemini vurgular çünkü yapıyı ancak bu kullanım anlamlı hale getirir. Bölümün sonuna doğru dil, metin, yazar, eleştiri kavramlarına yapısalcılar gibi bakmayan düşünce akımlarının ortaya çıktığı anlatılır. Uçan, bu akıma 
karşııt görüşler ortaya atan postyapısalcıların fikirlerine değinerek yapısalcıların eksik yönlerini ortaya koyar.

"R. Barthes, T. Todorov, A.j. Greimas ve Edebiyat Bilimi” başlıklı bölümde ismi geçen bu kuramcıların metin bağlamında ortaya attıkları görüşlerinin edebiyatla oluşturduğu ilişkiden söz edilir. Bu başlık altında T. Todorov'a daha çok yer veren yazar, Todorov'un 'poetika' kavramını da 'şiir' değil, 'edebiyat bilimi' (s.55) anlamında kullanması üzerinde durur. Poetika sözcüğüyle karş1ladığı tüm yazınsal metinlerde anlam sınırsızdır yani Todorov metinler üzerinde çözümleme yaparken yorumlarla çok anlamlılığa varmak gerektiğini anlatır. Uçan, Barthes'in “... edebiyat biliminin nesnesi, yapıta tek bir anlam yükleyip, bu anlama adına diğer tüm anlamları yok saymak olmayacaktır.” (s.59) sözüne yer vererek Todorov'un hocasından etkilendiğini göstermiş olur. Bununla birlikte yazınsal ürünleri çözümlerken metnin 'kesitleme' denilen yöntemle küçük parçalara ayırılması gibi birçok noktada birleşen Todorov ve Barthes'in düşüncelerinin Greimas tarafindan sistemleştirilmesi üzerinde durulur.

Diğer bölümlerde olduğu gibi “Söylem Göstergebilimi ve Duygu Değeri: Tevfik Fikret'in II. Abdülhamit Han ile İlgili Yazdığ 1 Şiirler” bölümünde de anlam üzerinde durulur ve bu konu hakkında fikir beyan eden Derrida, Fontanille, Greimas, C.Zilberberg gibi isimlere yer verilir. Kitap boyunca yazınsal metinlerin okuyucuya göre çok anlamlılık kazandığı sıklıkla dile getirilir. Uçan bu bölümde ise çok anlamlılığı meydana getiren 'duygu değeri' kavramını örneklerle açıklar. Duyguların şiirlerde yoğun olarak bulunmasından hareketle yazar, duygu yoğunluğunun fazlaca hissedildiği bir şair olan Tevfik Fikret'in şiirlerinden yola çıkarak bu 'değer'i anlamlandırmaya çalışır. Fikret'in izlek olarak aynı olan iki şiirini inceleyen Uçan, duygu dünyasındaki kararsızlıklarından ötürü, içerik olarak farklı şiirler ortaya koyduğu sonucuna varır.

"Yazınsal Kuramlar, Göstergebilim ve Edebiyat Eğitimi" ile "Edebiyat Eğitimi/ Estetik Bir Hazın Edinimi” başlıklı iki ayrı bölümde ağırlıklı olarak edebiyat eğitiminin anlatılması sebebiyle bu bölümler bir paragrafta incelenmeye müsaittir. "Yazınsal Kuramlar" başlıklı kısımda yansıtma kuramı, psikanaliz, yeni eleştiri, yapısalcı, alımlama estetiği gibi kuramlara kısaca değinilip göstergebilim kuramı üzerinden yazar-metin-okuyucu kavramları hakkında açık- 
lamalarda bulunulur. Göstergebilimin edebiyat eğitimine katkılarından bahseden yazar, "Edebiyat eğitiminde, göstergebilim, alımlama estetiği vb. yazınsal kuram ve yöntemlerin yazar/metin/okuyucu bağlamında sunduğu görüşlerden yararlanılmalıdır düşüncesini savunur. Edebiyat tarihi ağırlıklı olan bir edebiyat eğitimi değil, metne yönelen, metinden hareket eden, metinle karşı karşıya gelen bir edebiyat eğitimi öne çıkarılmalıdır.” (s.105) diyerek bu eğitimin nasıl verilmesi gerektiği ile ilgili düşüncelerini okuyucuya sunar.

“Dilin İşlevleri ve 1929 Müfredat Programı” başlığı altında dilin ileti, alıcı, gönderici, gönderge, kod, kanal işlevlerini örneklerle zihinde oturtmaya çalışan Uçan, 1929 müfredatında edebiyat eğitimiyle ilgili belirlenen maddelere yer vererek bu eğitimin öğrenciler için önemini vurgulamaya çalışır. Müfredat programına göre edebiyat, bir bilgilendirme nesnesi olarak değil de sanat olarak görülmelidir. Müfredatın bu maddesiyle Uçan'ın önceki bölümlerde sıkça bahsettiği göstergebilimin metinlere yaklaşma biçimine paralel olarak yazarın yerine eserin anlamı ön plana çıkarılmak istenir. Devamında müfredatın önemli birkaç maddesine atıf yapılarak bölüm bitirilir.

Uçan, Türk edebiyatının önemli isimlerinin Necip Fazıl Kısakürek ve onun tarafından çıkartılan Büyük Doğu mecmuasına yer vererek eserinde dile getirdiği düşünceleri somutlaştırır. Necip Fazıl yaşadığı dönemin ideolojisine karşı olan bir sanatçıdır. Verdiği eserlerle de korkusuzca düşüncelerini dile getirmeyi başarır. "Mesaj Dili Olarak Büyük Doğu Kapakları” adlı başlık altında Necip Fazıl'ın çıkarttığı 'Büyük Doğu' dergisinin içerik ve kapağının insanları kendi ideolojisine yönlendirmesinden bahsedilir. Necip Fazıl, okuyucuyu etkilemeye kapakta geçen slogan niteliğindeki cümleleriyle başlar. Kapak ve başlıklarda kullandığı sert söylem sayesinde okuyucuyu derginin içeriğini okumaya zorlar. Bölüm boyunca 'dilin işlevleri'nin Büyük Doğu dergisinde nasıl yansıtıldığı tartışılır.

Edebiyat Bilimi kitabının ikinci ana bölümü olan "Üslup Arayışları/Kısa Öykü/Küçürek Öykü” başlığı altındaki ilk bölüm “Üslup Arayışları ve Yusuf Atılgan'ın 'Aylak Adam'1'”, ismini taşır. Kitapta bu romana yer verilmesinin nedeni yazarın “Özellikle Aylak Adam, anlatı tekniği, üslubu, düşünce ve duyguları dile getiriş biçimiyle kendisinden önceki anlatılardan farklı bir görünüme 
sahiptir." (s.154) ifadesine bağlanabilir. Atılgan'ın romanına kadar Türk edebiyatını etkileyen akımlardan bahseden Uçan, bu romanı modernist akımın temsilcisi oluşundan ötürü diğerlerinden ayrı bir yere koyar. Atılgan Aylak Adam romanıyla kendisine kadar yazılmışlardan farklı bir üslup yakalamayı başarır ve Uçan, Atılgan'1n romanından örnekler vererek düşüncelerini destekler.

“Kısa Öykünün Özellikleri” başlı̆̆ı altında ise kısa öykünün tanımı, klasik öyküden farkları ve bu türü okunur kılan birtakım hususlar üzerinde durulur. Uçan, "Kısa öykü için bir olay, bir düşünce, bir an üzerinde odaklanan, fazlalıklardan arıtılmış yazınsal bir türdür diyebiliriz." tanımıyla bu türün özelliklerini ve klasik öykü türünden ayrılan yönlerini ifade eder. Kısa öykünün okunması için hangi özeliklere sahip olması gerektiğini sıralayan Uçan, bu özellikleri Çehov ve Maupassant öykülerinde inceler.

İkinci bölümün üçüncü başlığı olan "Küçürek Öykü Üzerine: Mehmet Harmancının 'Muhtemel Menkıbeler'i”nde kısa öykünün de kısası sayılan, bir noktanın bile anlatı sayılabileceği tür 'küçürek öykü'nün özelliklerine yer verilir. Bu özellikleri desteklemek adına Mehmet Harmancı'nın 'Muhtemel Menk1beler' kitabından örnekleri inceleyen yazar, “Harmancı'nın kurduğu cümleler kısa, ama okuyucuyu derinlemesine düşündüren cümleler." tespitini yaparak eserinin küçürek öykü türüne uygun olduğunu dile getirir.

Hilmi Uçan kitabının "Guy de Maupassant / E. A. Poe / F. Kafka ve Fantastik Anlatı" isimli son yazısını okuyucuyu hayal ile gerçek arasında kararsızlık içinde bırakan tür olan fantastik anlatının özelliklerine değinerek başlatır. Uçan, bölümün devamında Maupassant, Poe ve Kafka'nın öykülerinde fantastik türü nasıl yansıttıklarına örnekler vererek üç yazarın bu türdeki ortaklıklarını tespit eder.

Sonuç olarak, Edebiyat Bilimi adlı bu çalışmada göstergebilim, yapısalcılık, alımlama estetiği, yeni eleştiri gibi çeşitli kuramlar temel metinlere dayandırılarak anlatılır. Birinci bölümde göstergebilim kuramı örnekler ve açıklamalar üzerinden somutlaştırmaya çalışılır. Bu sayede anlamlandırması hayli zor olan kuramların örneklerle desteklenmesi okuyucunun kuramları kolayca algılamasına yardımcı olur. Hilmi Uçan'ın bu çalışmasında sadece kuram değil eleştiri, şiir, roman, öykü türlerine de yer vermesi anlatmak istediklerinin zen- 
ginleşmesini sağlar. Eserin diline bakıldığında bölümleri oldukça sade bir şekilde ifade ettiği görülür. Yazar, kuramlar hakkında yazılan temel metinleri eleştirel bir üslupla inceler. Birçok kuramın açık, anlaşılır bir dille karşılaştırmalı olarak verildiği bu eser, yazınsal alandaki kuramları rahatlıkla anlamlandırmaya yardımcı olacak düzeydedir. 